\title{
ENTREPRENEURS' OBLIGATIONS TO DISCLOSURE, RECORDING, BILLING, AND THE SAFE-KEEPING OF BILLS WITH REGARD TO VAT
}

\author{
PIERRE FROTSCHER*
}

\section{INTRODUCTION}

In connection with the new regulation of entrepreneurship of the public sector in para $2 \mathrm{~b}$ of the German Value Added Tax Act (hereinafter: $\mathrm{UStG})^{1}$, the legislator granted legal entities of public law (hereinafter: 1.e.p.1.) the right to use the former regulation of para $2 \sec 3 \mathrm{UStG}$, i.e. the previous regulation ${ }^{2}$, until 31.12 .2020 in para $27 \mathrm{sec} 22 \mathrm{cl} 3 \mathrm{UStG}$. According to this regulation, tasks which have a sales volume of less than 35.000 EUR, are part of the pure asset management sector, part of the agriculture or forestry sectors, or have been assigned to the public sector, can be excluded from taxation of turnover until 31.12.2020 if the 1.e.p.l. concerned declares the option effective to the competent fiscal authority ${ }^{3}$.

On the other hand it may be of interest to relinquish such an option and to apply the new regulation immediately, especially to achieve a deduction of input tax in the case of planned investments. Tasks that so far have been classified as non-entrepreneurial would then expand the entrepreneurial tasks of the 1.e.p.l or, if the 1.e.p.l. has not been liable to pay VAT for other tasks so far, would constitute its entrepreneurial status.

The VAT-liable entrepreneurial status has a number of further obligations and duties, though, which not only lead to high efforts and expenditures, but which can incur sanctions and disadvantages if the obligations and duties are not fulfilled.

This text shall give an overview over the entrepreneurs' obligation to disclose, record, bill and safe-keep bills with regard to VAT.

DOI: $10.1515 /$ wrlae-2015-0057

* PhD in Law, Lecturer at the Department of Tax Administration, Meissen University of Applied Administrative Sciences, Centre for Continuing Education; pierre.frotscher@hsf.sachsen.de

${ }^{1}$ Cf. Fritz Lang, 'Taxation of the public sector in Germany - an introduction', in this volume.

2 On former regulations and administrative interpretation cf. Pierre Frotscher, 'Umsatzbesteuerung der Kommunen -Rechtliche Rahmenbedingungen in der EU und im nationalen Recht sowie aktuelle Entwicklungen in der Rechtsprechung (2013) 4 Sachsenlandkurier 254 et seq.

3 This concession of the national legislation is not without problems as it defies the decisions of the CJEU and therefore European guidelines. 
To do so, the legal requirements will be discussed and summarized with a supplementary analysis of administrative orders and the relevant literature. This will offer the 1.e.p.l. concerned by the regulations an overview over additional administrative obligations, and enable them to better estimate the effort necessary for the expected legal consequences.

\section{The OBLigation to Disclose With REGARD to VAT}

An entrepreneur in the sense of the VAT-act has a number of obligations to disclose, especially his obligation to a tax declaration.

In addition, there are further special obligations to disclose. They are less important for 1.e.p.l., but are not completely unlikely and shall therefore be explained briefly.

\section{The Obligation to a Tax DeClaration}

According to para $149 \mathrm{sec} 1 \mathrm{cl} 1$ of the German Fiscal Code (AO), the tax laws determines who has to file a tax report.

For the VAT, this is mainly regulated in para 18 UStG. As a basic principle, every entrepreneur is therefore obliged to declare advance sales tax returns as well as an annual sales tax return.

The duties to declare are independent of the existence of taxable and declarable turnovers ${ }^{4}$. Even small businesses in the sense of para 19 UStG, which are exempt from the VAT liability, are obliged to declare an annual sales tax return ${ }^{5}$.

Legal entities - including 1.e.p.l. - that are not entrepreneurs have to provide a tax declaration according to para $18 \mathrm{sec} 4 \mathrm{a}$ UStG, if they owe VAT for the intra-community acquisition according to para $1 \mathrm{sec} 1 \mathrm{no} 5$ in conjunction with para $1 \mathrm{a} \mathrm{UStG}^{6}$ or as recipient of benefits according to para $13 \mathrm{~b}$ sec $5 \mathrm{UStG}^{7}$.

The sales tax returns have to not only include all facts relevant to levying the taxes, but the entrepreneur must calculate the VAT, according to

\footnotetext{
${ }^{4}$ Cf. Axel Leonard in Bunjes Umsatzsteuergesetz Kommentar (13th edn CH Beck 2014) para $18 \mathrm{~m}$. n. 3 .

5 Cf. German Federal Finance Court (BFH), decision of 24.7.2013, Ref.: XI R 14/11, BStB1. II 2014, 210; small-scale entrepreneurs do not have to provide advance VATdeclarations, c.f. A 18.7. sec 1 p., 4 Circular on the Application of the VAT (UStAE).

${ }^{6}$ This would be the case if the non-entrepreneurial 1.e.p.l. purchases goods - with the exception of new vehicles in the sense of para $1 \mathrm{~b}$ sec 2 and 3 UStG or excisable goods in the sense of para 1 a sec 5 p. 2 UStG - from other member states of the EU exceeding a netamount of 12.500 EUR or if the 1.e.p.l. opted for sales taxation by indicating a German VAT-No.

${ }^{7}$ A relocation of the tax liability towards the beneficiary of the good can be contemplated if other goods or services are purchased from foreign companies, cf. para $13 \mathrm{~b}$ sec 1 and 2 no 1 in conjunction with sec 5 UStG. Especially if construction work is purchased from foreign companies, there is a general relocation of tax liability towards the beneficiary of the good, if the beneficiary is an entrepreneur or a legal entity.
} 
para $18 \mathrm{sec} 1 \mathrm{cl} 1$ and $3 \mathrm{UStG}$, himself. According to para $150 \mathrm{sec} 1 \mathrm{cl} 3$ $\mathrm{AO}$, these tax declarations are therefore tax self-assessments.

\subsection{The Advance Sales Tax Returns}

According to para $18 \mathrm{sec} 1 \mathrm{cl} 1 \mathrm{UStG}$ every entrepreneur has to declare an advance no later than 10 days after the end of the advance declaration period.

\subsubsection{Period for the Advance Declaration}

The period for the advance declaration according to para $18 \mathrm{sec} 2 \mathrm{cl}$ $1 \mathrm{UStG}$ is, in principle, the calendar quarter. If the tax for the preceding calendar year has been higher than 7.500 EUR, the period for the advance declaration is the calendar month according to para $18 \sec 2$ sentence 2 UStG.

In the case of starting up, i.e., in cases where the entrepreneurial or professional occupation is taken up for the first time, there is an obligation to monthly advance declarations for VAT in the year of starting up and the following year according to para $18 \mathrm{sec} 2 \mathrm{cl} 4$ UStG. In those cases where, in conjunction with para $2 \mathrm{~b}$ UStG, there is an entrepreneurial status of the 1.e.p.l. for the first time, this is, in my opinion, not a case of a start-up in the sense of para $18 \mathrm{sec} 2 \mathrm{cl} 4 \mathrm{UStG}$. What is new is only the legal classification of its tasks.

To realise a prompt reimbursement of the advance-tax, para $18 \mathrm{sec}$ 2a UStG allows the entrepreneur a monthly advance declaration if the surplus in favour of the entrepreneur in the last calendar year exceeded 7.500 EUR. In this case, the entrepreneur has the right to choose, which he executes by handing in the advance declaration for the calendar month January no later than February $10^{\text {th }}$ of the current year.

If the VAT to be paid in the last calendar year was less than 1.000 EUR, the fiscal authority can release the entrepreneur of his obligation to an advance declaration for the VAT according to para $18 \mathrm{sec} 2 \mathrm{cl} 3$ UStG. If the 1.e.p.l. is obliged to pay VAT for the first time due to the change of the regulations in para $2 \mathrm{~b}$ UStG, I believe it would be helpful to focus on whether the VAT to be paid in the running calendar year is not more than 1.000 EUR. In this case, the 1.e.p.l. should apply for a dispensation by explaining this case.

\subsubsection{Periods of Declaration}

The advance declaration for VAT has to be handed in no later than the $10^{\text {th }}$ day after the end of the time period of the declaration, i.e., at the $10^{\text {th }}$ of the following calendar month or calendar quarter, at the latest. If the deadline is on a Saturday, Sunday or a holiday, the period of declaration is extended until the next working day according to para $108 \mathrm{sec} 3 \mathrm{AO}$. 


\subsubsection{Permanent Extensions of Declaration Periods}

According to para $18 \mathrm{sec} 6 \mathrm{UStG}$ in conjunction with para 46 UStDV the fiscal authority can grant a so-called permanent extension of the period of declaration and prolong the period of declaration by one month.

In this case, according to para $48 \mathrm{sec} 1 \mathrm{cl} 2 \mathrm{UStDV}$ the entrepreneur must apply for the prolongation with official mandatory data $\operatorname{set}^{8}$ by electronic data transmission according to the regulation for the transmission of tax data (StDÜV) at his local fiscal authority. Since 01.01.2013, only an authenticated transmission, where the entrepreneur has to register in advance at the Elster-Online-Portal of the fiscal authorities, is allowed. On application, there is an option to avoid this electronic transmission if undue hardship must be avoided; in the case of 1.e.p.l. it is highly unlikely that this can be justified, though.

If the entrepreneur has to provide a monthly advance declaration, granting the prolongation according to para $47 \mathrm{UStDV}$ is only possible if the entrepreneur pays a special advance amounting to $1 / 11$ of the sum of advance payments of the last calendar year. This special advance must be calculated, announced and paid by the entrepreneur. If the 1.e.p.l. is obliged to pay VAT for the first time due to the change of the regulations in para $2 \mathrm{~b}$ UStG, the focus should be on the expected VAT for the running calendar year according to para $47 \mathrm{sec} 3$ UStDV.

\subsubsection{Form and Content of the Advance Declaration}

According to para $18 \mathrm{sec} 1 \mathrm{cl} 1 \mathrm{UStG}$ advance declarations for VAT have to be transmitted to the fiscal authority with the official mandatory data set $^{9}$ by electronic data transmission according to the regulation for the transmission of tax data (StDÜV) at his local fiscal authority.

Every entrepreneur has to provide only one advance declaration for every advance period, which has to include all required information ${ }^{10}$. This is also the case if the company consists of a number of firms or, in case of 1.e.p.l. of a number of commercial enterprises. If applicable, integrated controlled companies must be included ${ }^{11}$.

\footnotetext{
${ }^{8} \mathrm{Cf}$. the model form (Vordruckmuster) USt $1 \mathrm{H}$ published for 2016 by the federal ministry for finances (BMF) 2.10.2015, BStB1. I 2015, p. 773; cf. Leonard (n 4), para 18 m. n. 22; Josef Heß in Rüdiger Weimann, Fritz Lang (eds), Umsatzsteuer - national und international (4th edn Schäffer-Poeschel Verlag 2015) para 18 m. n. 35 ff. for the process of application for the permanent extension of declaration periods.

${ }^{9} \mathrm{Cf}$. the model forms (Vordruckmuster) USt 1 A and instruction USt 1 E published for 2016 by the Federal Ministry for Finances (BMF) on 2.10.2015, BStB1. I 2015, 773.

${ }^{10}$ Otto-Gerd Lippross, Umsatzsteuer (23th edn Erich Fleischer Verlag 2012) 1224.

${ }^{11}$ Cf. Pierre Frotscher, Heiko Schröder 'Die Organschaft im Körperschaft-, Gewerbe- und Umsatzsteuerrecht bei juristischen Personen des öffentlichen Rechts' (2014) 5 Sachsenlandkurier 239 for the requirements and legal consequences of the integrated company.
} 
In reality, most entrepreneurs only have to fill in a few parts of the official mandatory data set, especially information about the company, taxable sales, deductible input tax and the resulting tax. The DATENSATZ contains a large number of further items, which an entrepreneur can hardly understand and fill in without legal support ${ }^{12}$.

\subsubsection{EFFeCt Of THE AdVANCE DEClaration}

The receipt of an advance declaration with a payment charge for the entrepreneur has the effect of a tax assessment with the reservation of reaudit para $164 \mathrm{sec} 1 \mathrm{cl} 2$ in conjunction with para $168 \mathrm{sec} 1 \mathrm{AO}$. Therefore, the tax calculated and paid by the entrepreneur is an advance payment that is due by the $10^{\text {th }}$ day after the end of the period of the advance declaration, cf. para $18 \mathrm{sec} 1$ p. 1 and 4 UStG. If the deadline is on a Saturday, Sunday or a holiday, in this case as well, the period of declaration is extended until the next working day according to para $108 \sec 3 \mathrm{AO}^{13}$. If the tax is not paid in due time, there is a charge for delayed payment according to para $240 \mathrm{sec} 1$ point $1 \mathrm{AO}^{14}$. If the tax is paid by transfer order, para $240 \mathrm{sec} 3 \mathrm{cl} 1 \mathrm{AO}$ grants a three-day grace period.

If, according to the advance declaration for the VAT, there is a surplus in favour of the entrepreneur, the declaration of this tax refund only is on par with a tax assessment with the reservation of re-audit, if the fiscal authority agrees, para $168 \mathrm{cl} 1 \mathrm{AO}$. Usually, this happens implicitly with the payment of the declared tax refund. If the fiscal authority has doubts, though, it can evaluate more thoroughly or even do an audit on-site.

If the tax assessment is under the reservation of re-audit, and the appointment period $^{15}$ is not expired yet, it can be adjusted according to para $164 \sec 2 \mathrm{cl} 1 \mathrm{AO}$.

\subsection{Annual Sales Tax Return}

In addition to the advance declaration of the VAT, the entrepreneur has to provide an annual sales tax return for the whole calendar year according to para $18 \mathrm{sec} 3 \mathrm{UStG}$. The filing of the annual tax return is

\footnotetext{
12 Explicitly in Martin Kemper, 'Erklärungspflichten des Umsatzsteuergesetzes' (2015) Umsatzsteuer- Rundschau 374.

13 Hans-Georg Janzen in Otto Gerd Lippross, Wolfgang Seibel (eds), Basiskommentar Steuerrecht (Verlag Dr. Otto Schmidt 2010) para 18 UStG m. n. 78.

14 The charge for delayed payment is roughly $1 \%$ of the overdue tax per commenced month delayed. If, for example, an advance VAT-payment of 14.133 EUR is due on 10.2. and is paid on 12.3., the charges for delayed payment are imposed for two months for the rounded down amount of 14.100 EUR, and therefore amount to 282 EUR.

${ }^{15}$ The appointment period for the VAT is, in principle, 4 years according to para $169 \mathrm{sec} 2$ no $2 \mathrm{AO}$ and generally starts with the end of the calendar year in which the tax was generated (para 170 para $1 \mathrm{cl} 1 \mathrm{UStG}$. The elements of the statutory period regulated in para $170 \mathrm{sec} 2 \mathrm{AO}$ routinely delay the commencement of the term.
} 
independent of, and parallel to, the advance declaration. Filing the annual tax return does not lead to a dispensation from the advance declarations ${ }^{16}$.

\subsubsection{TERM OF DECLARATION}

The annual sales tax return has to be submitted by March 31 st of the following year in principle, according to para $149 \mathrm{sec} 2 \mathrm{cl} 1 \mathrm{AO}$. If the tax return mentioned above is prepared by tax consultants, the time period is extended until 31.12. of the following year according to para $109 \mathrm{AO}^{17}$.

The law for the modernisation of the system of taxation ${ }^{18}$ stipulates a general filing deadline of 7 months, starting from 2017. In case of tax consulting, the deadline is extended to 14 months until 28.2. of the second year after the year declared. In those cases, the financial authority can request an earlier declaration under certain circumstances, but must observe a grace period of 4 months when doing so.

\subsubsection{Form And Content of the Annual Sales Tax Return}

According to para $18 \mathrm{sec} 3 \mathrm{cl} 1 \mathrm{UStG}$, the annual sales tax return has to be transmitted to the fiscal authority with the official mandatory data $\operatorname{set}^{19}$ by electronic data transmission according to the regulation for the transmission of tax data (StDÜV) at the competent fiscal authority.

\subsubsection{EFFECT OF the AnNual Declaration}

If the tax to be paid according to the calculations of the annual sales tax return is different from the sum of the advance payments, a difference in favour of the fiscal authority must be paid one month after submission of the annual sales tax return according to para $18 \mathrm{sec} 4 \mathrm{cl} 1$ UStG.

If there is a surplus for the entrepreneur, because the sum of the advance payments, especially the sales tax prepayment according to para 47 UStDV, was higher than the actual annual tax, the refund is only due with the approval of the fiscal authority, para $168 \mathrm{cl} 2 \mathrm{AO}$.

\footnotetext{
${ }^{16}$ Leonard (n 4) para 18 m. n. 23.

${ }^{17} \mathrm{Cf}$. identical decrees of the supreme fiscal authorities of the federal states, 4.1.2016 on periods for tax returns, BStB1. I 2016, p. 38.

18 Cf. BT-Drs. 18/7457, 3.2.2016 and BT-Drs. 18.8434, 11.5.2016 - cf. also Jörg Schwenker, 'Das Gesetz zur Modernisierung des Besteuerungsverfahrens - ein Meilenstein auf dem Weg der weiteren Digitalisierung im Steuerrecht' (2016) Der Betrieb 375 et seq.

19 Cf. the model form for the annual sales tax return 2015 published by the federal ministry for finances 1.10.2015, BStB1. I 2015, 758 .
} 


\subsection{Consequences in the Case of a Delayed SUBMISSION OR NON-SUBMISSION}

If an advance declaration for VAT or the annual sales tax return is not handed in, the fiscal authority can impose a charge for delayed payment according to para $152 \mathrm{sec} 1 \mathrm{cl} 1 \mathrm{AO}$. This charge can be up to $10 \%$ of the tax due. The law for the modernisation of the system of taxation will presumably lead to considerable changes with regard to the charge for delayed payment, starting in 2017. Especially in the case of a delayed submission, there is a mandatory charge for delayed submission of at least 25 EUR per month, or part thereof, delayed.

In addition, the fiscal authority can estimate the tax base according to para $162 \mathrm{AO}$ in case of non-submission.

Negligence, in terms of non-submission contrary to duty or submission of incorrect or incomplete tax returns, can be considered as tax fraud, and therefore an offence according to para $370 \mathrm{AO}$, or a tax evasion, and therefore an administrative offence according to para $378 \mathrm{AO}$.

If an entrepreneur does not fulfil his fiscal duties, the fiscal authorities are, under certain circumstances, entitled to withdraw beneficial administrative acts, e.g., the permanent extension of the declaration period for the submission of the advance declarations for VAT according to para 47 UStDV.

\section{FURTHER MANDATORY DEClaRATIONS}

In addition to the obligation to a sales tax return, in some cases there may be other mandatory declarations ${ }^{20}$.

\subsection{THE SUMMARY STATEMENT OF TURNOVER ACCORDING TO PARA 18A USTG}

The summary statement of turnover (SST) is used by the fiscal authorities to secure the tax revenue of the European Single Market and to trace cross-border deliveries and services within the territory of the community. Accordingly, an entrepreneur exporting a good or service to another member state of the EU must state these sales in a SST.

The SST is a legal obligation in the taxation system and the entrepreneur must declare those turnovers monthly in case of exports within the EU according to para $18 \mathrm{a}$ sec $1 \mathrm{UStG}$, or quarterly in case of special exports $^{21}$ according to para 18 a sec 2 UStG. The SST has to be submitted to the Federal Central Tax Office '(BZSt) until the $25^{\text {th }}$ day after expiration of the relevant notification period.

\footnotetext{
20 Cf. also Kemper (n 12) 375 et seq.

21 This only includes goods and services with turnover in regions in the further regions of the community according to para 3 a sec 2 UStG where the receiving entrepreneur is obliged to pay the tax.
} 
The content of the SST to be submitted with the official mandatory data set by electronic data transmission according to the regulation for the transmission of tax data (StDÜV) is regulated in para 18a sec 7 UStG and includes, e.g., the VAT identification number (USt-IdNr.) of the customers and the assessment basis for the goods or services delivered.

For 1.e.p.l., the submission of a SST is usually of little importance. But if, e.g., there is an advertisement of a Czech company in a community newspaper in Germany, this would be a case for a SST, because the municipality acts as an entrepreneur in this case ${ }^{22}$ and is no small-scale entrepreneur within the meaning of para $19 \mathrm{UStG}^{23}$.

If there is an obligation to submit a SST, the submission of an incorrect or delayed SST or the non-submission are an administrative offence according to para 26a sec 1 no 5 UStG.

\subsection{SPECIAL DECLARATION OF INTRA-COMMUNITY EXPORTS AND SPECIAL OTHER SERVICES AND GOODS ACCORDING TO PARA 18B Ustg}

In addition to para $18 \mathrm{a}$ UStG, para $18 \mathrm{~b}$ UStG states that the entrepreneur must declare intra-community exports as well as certain exports within the further regions of the community ${ }^{24}$ to the fiscal authorities.

Para 18a UStG is expected to ensure that data transmitted for the SST to the Federal Central Tax Office concurs with data submitted to the fiscal authorities and can be compared.

The official forms for the advance declaration for VAT and the annual sales tax return are complemented by corresponding spaces, so that declarations can be made together with the regular advance declaration or annual sales tax return.

\footnotetext{
${ }^{22}$ Under the regulations of the previous para $2 \sec 3 \mathrm{UStG}$, the entrepreneurial status is precluded for those with an annual revenue of less than 35.000 EUR; under the new regulations of para $2 \mathrm{~b} U \mathrm{UStG}$, a structure under public law and an estimated annual revenue of less than 17.500 EUR for those activities are necessary to preclude the entrepreneurial status.

${ }^{23}$ The SST, according to para 18 a sec 4 UStG, does not have to be submitted by smallscale enterprises according to para 19 UStG. The regulation for small-scale enterprises according to para $19 \mathrm{UStG}$ assumes that the gross turnover of the previous year was less than 17.500 EUR and does not exceed 50.000 EUR in the current calendar year.

24 The regulation also includes the declaration of deliveries according to para $25 \mathrm{~b}$ sec 2 UStG. para $25 \mathrm{~b}$ UStG regulates the intra-community triangular trade. It assumes that three entrepreneurs from different member states carry out turnover transactions and the goods are directly delivered from the first entrepreneur to the final buyer. This is likely not relevant for 1.e.p.1.
} 


\subsection{The Obligation to Register the Delivery OF NeW VeHICLES ACCORDING TO PARA 18C USTG}

If new vehicles are delivered to a buyer from another member state within the community, and this buyer does not use a VAT identification number25, the obligation to register according to para $18 \mathrm{c}$ UStG in conjunction with the regulation for obligatory registration of delivery of vehicles (Fahrzeuglieferungs-Meldepflichtverordnung $=$ FzgLiefgMeldV) must be observed.

It is important to note, for example, that a vehicle is considered new according to para $1 \mathrm{~b} \sec 3 \mathrm{UStG}$, if it has not been driven for more than $6.000 \mathrm{~km}$ or if has been brought into service less than six months ago.

In addition, if new vehicles are sold, even non-entrepreneurial suppliers are treated as entrepreneurs according to para $2 \mathrm{a}$ UStG and have to observe the registration requirements.

If, e.g., a municipality sells a car that has been driven for less than $6.000 \mathrm{~km}$ to a Polish private individual, then it has to observe the registration requirements according to para $18 \mathrm{c}$ UStG in conjunction with the FzgLiefgMeldV, irrespective of the former use for public administration or for entrepreneurial purposes.

In case of obligatory registration, a large amount of information has to be transmitted to the BZSt by the $10^{\text {th }}$ day after the end of the calendar quarter of the delivery ${ }^{26}$.

Entrepreneurs have to submit their registration by the official mandatory data set by electronic data transmission according to the StDÜV. Non-entrepreneurial suppliers are allowed to submit their registration on paper, using the official mandatory form ${ }^{27}$.

The incorrect, omitted or delayed registration is considered an administrative offense according to para $26 \mathrm{a}$ cl 1 no 6 UStG.

\section{MANDATORY RECORD-KEEPING FOR ENTITIES SUBJECT TO VAT}

In addition to mandatory declarations for entities subject to VAT, the entrepreneur has to observe a number of obligations for record-keeping.

According to para $22 \mathrm{sec} 1 \mathrm{cl} 1 \mathrm{UStG}$, the entrepreneur has to provide records for the determination of the tax and the basis for its calculation ${ }^{28}$. Generally, the entrepreneur fulfils his mandatory recordkeeping with regard to VAT by standard accounting. According to para 22

\footnotetext{
25 If the entrepreneur uses a VAT identification number, the transaction is considered a regular intra-community transaction that has to be declared according to para $18 \mathrm{a}$ and para $18 \mathrm{~b}$ UStG.

${ }^{26}$ The content of the registration is specified in para 2 FzgLiefgMeldV and A $18 \mathrm{c} .1$ sec 4 UStAE.

${ }^{27} \mathrm{Cf}$. A $18 \mathrm{c} .1 \mathrm{sec} 2$ and 3 UStAE and the information on www.elster.de and www.bzst.de.

${ }^{28}$ Cf. general UStAE on para 22 UStG; Lippross (n 10) 1268 et seq; Hans-Hermann Heidner in Bunjes Umsatzsteuergesetz Kommentar (13th edn CH Beck 2014) para 22 m. n. 1 et seq.
} 
sec 2 no 1 UStG the records must include the payments for services and goods provided by the entrepreneur, observing the differentiation between taxable turnover (separated by tax rate) and tax-exempt turnover. For the deduction of input tax, the remuneration for taxable goods and services paid to the entrepreneur for the company have to be recorded according to para $22 \sec 2$ no 5 UStG.

According to para $63 \mathrm{sec} 1 \mathrm{UStDV}$, the records must be provided in a form that enables an expert third party to get an overview of the turnover of the entrepreneur and the deductible input tax within a reasonable period. The sales receipts indispensable elements of the records.

According to para $146 \mathrm{sec} 2 \mathrm{cl} 1 \mathrm{AO}$, the records have to be made basically in the German territory.

In case of missing or incomplete records, the fiscal authority is entitled to estimate the tax base according to para $162 \mathrm{AO}$, and uncertainties connected with the estimation are at the expense of the entrepreneur ${ }^{29}$. Culpable violations of the record requirements constitute an administrative offense according to para $379 \mathrm{AO}$.

In addition to the mandatory record-keeping according to para 22 UStG, there are special obligations to provide evidence for the entitlement to certain tax exemptions. Non-taxable export-deliveries or nontaxable intra-community deliveries, for example, must be proved by accounting and the provision of receipts. If the proof is missing, the tax exemption is not granted.

\section{OBLIGATION TO ISSUE AND STORE INVOICES}

According to para $14 \mathrm{UStG}$, the entrepreneur is obliged to issue a qualified invoice to the recipients of goods and services in a large number of cases.

In addition, he is obliged to keep a duplicate of all invoices issued and received according to para $14 \mathrm{~b}$ UStG.

\section{OBLIGATION TO ISSUE AN INVOICE}

An entrepreneur is obliged to issue an invoice for certain propertyrelated services, especially construction services, but also property development, gardening and cleaning services ${ }^{30}$ according to para $14 \sec 2$ no 1 UStG.

In addition to this specific obligation to issue invoices, para $14 \mathrm{sec} 2$ no 2 UStG regulates a general obligation to issue invoices if the entrepreneur provides services or goods to another entrepreneur for his

\footnotetext{
${ }^{29}$ Lippross (n 10) 1269.

30 Lippross (n 10) 883; Fritz Lang in Rüdiger Weimann, Fritz Lang (eds), Umsatzsteuer national und international (4th edn Schäffer-Poeschel Verlag 2015) para 14 m. n. 37 et seq.
} 
company or to a non-entrepreneurial legal entity, and the turnover is not taxexempt according to para 4 nos 8 to 29 UStG.

In all other cases, i.e. non-property-related services to nonentrepreneurs, the entrepreneur is not obliged to issue an invoice with regard to VAT. Voluntarily or based on contractual agreements, an invoice can be issued in these cases as well.

\section{FORM OF THE INVOICE}

According to para $14 \mathrm{sec} 1 \mathrm{cl} 1 \mathrm{UStG}$, an invoice is every document used to charge for a service or good. It can be issued in paper form or, since 1.7.2011, electronically.

The authenticity of the origin, i.e. the identity of the issuer of the invoice, the integrity of the content and the legibility of the invoice must be ensured $^{31}$. How this is realised is for the entrepreneur to decide.

\section{CONTENT OF A QUALIFIED INVOICE}

The requirements for the contents of an invoice are stated in para 14 sec 4 nos 1 to 10 UStG. The entrepreneur has to state in particular:

- The complete name and address of entrepreneur and the recipient of goods or services (no 1). (no 2).

- $\quad$ His tax identification number or VAT identification number

- $\quad$ The date of issue (no 3).

- An invoice number (no 4).

- A description of the good or service (no 5).

- The date of the delivery or the date of receipt of the remuneration (no 6).

- $\quad$ The net remuneration (no 7).

- The tax rate and the amount of tax or a reference to the tax exemption (no 8).

- $\quad$ Reference to record retention, if applicable (no 9).

- $\quad$ Specification "credit", if applicable (no 10$)^{32}$.

Further mandatory contents are found in para 14a UStG. Especially in cases of reverse charging of tax, the invoice must include the specification "tax liability of the recipient of services".

For invoices for small amounts of less than 150 EUR (from 2017, expected to be less than 200 EUR) and tickets, the special regulations of paras 33, 34 UStDV apply.

\footnotetext{
31 Lippross (n 10) 880 et seq; Ronny Langer, Robert Hammerl, 'Rechnungen im Umsatzsteuerrecht' (2013) Neue WirtschaftsBriefe für Steuer- und Wirtschaftsrecht 1280 et seq.

${ }^{32}$ A credit exists in cases where the recipient of the service instead of the providing entrepreneur bills the service, cf. para $14 \sec 2 \mathrm{cl} 2$ and 3 UStG.
} 


\section{MANDATORY RETENTION AND Filing}

According to para $14 \mathrm{~b} \mathrm{sec} 1 \mathrm{cl} 1 \mathrm{UStG}$, every entrepreneur is obliged to retain all invoices issued or received by him.

The period of retention begins with the end of the calendar year where the invoice was issued and lasts 10 years. The period is prolonged in cases where the invoices are still relevant for taxes where the appointment period has not yet run out. If the period is not over yet, the authenticity of the origin, the integrity of the content and the legibility of the invoice must be ensured. Invoices issued on thermal paper may have to be copied to ensure legibility.

Invoices on paper may be scanned and digitally archived under certain circumstances ${ }^{33}$.

The repository is generally the German territory. Electronically stored invoices can be deposited in Community territory, if an immediate on-line access of the authorities is guaranteed.

\section{Consequences in CASE OF BREACH OF THE REGULATIONS}

If an invoice is not issued or not issued in time due to a culpable breach of the entrepreneur, this is considered an administrative offence due to para 26a sec 1 no 1 UStG.

If the VAT stated on the invoice is too high, the issuer of the invoice owes the excess amount according to para $14 \mathrm{c}$ sec 1 UStG.

If the supplying entrepreneur does not issue the invoice properly or not on time, this may justify claims for compensation by the recipient of the goods or services, because the deduction of his input tax depends on the invoices.

Culpable breaches of the mandatory retention of invoices are considered an administrative offence according to para 26a sec 1 no 2 UStG.

If the entrepreneur cannot provide proper purchase invoices, the fiscal authorities will not grant him the deduction of input tax according to para $15 \mathrm{sec} 1 \mathrm{cl} 1$ no 1 UStG.

\section{CONCLUSion}

An entrepreneur's obligations for declaration and record-keeping as well as mandatory issuing, retention and filing of invoices connected with the VAT alone are manifold and comprehensive. Without expert advice, the entrepreneur will unlikely be able to fulfil all of the obligations. The efforts and expenses of compliance must not be underestimated.

${ }^{33}$ Cf. Langer, Hammerl (n 31) 1292. 
The taxation of turnover according to previous law that exempted comparably large fields of activity of 1.e.p.l. from taxation, and thereby from compliance with further additional obligations in conjunction with taxation, is generally less complex and therefore more beneficial for many l.e.p.l. Taking this into consideration, it will be advantageous for many l.e.p.l. to exercise their option right and opt for the regulation of para $2 \mathrm{sec} 3$ UStG by declaring to their fiscal authority that they want to observe the previous regulations.

The transitional period until 31.12.2020 granted by the legislator should be used to examine activities according to the new regulations and to prepare for the new legislation according to the new para $2 \mathrm{~b}$ UStG.

\section{References}

Frotscher Pierre, 'Umsatzbesteuerung der Kommunen -Rechtliche Rahmenbedingungen in der EU und im nationalen Recht sowie aktuelle Entwicklungen in der Rechtsprechung (2013) 4 Sachsenlandkurier

Frotscher Pierre, Schröder Heiko, 'Die Organschaft im Körperschaft-, Gewerbe- und Umsatzsteuerrecht bei juristischen Personen des öffentlichen Rechts' (2014) 5 Sachsenlandkurier

Heidner Hans-Hermann in Bunjes Umsatzsteuergesetz Kommentar (13th edn CH Beck 2014)

Heß Josef in Weimann Rüdiger, Lang Fritz (eds), Umsatzsteuer - national und international (4th edn Schäffer-Poeschel Verlag 2015)

Janzen Hans-Georg in Lippross Otto Gerd, Seibel Wolfgang (eds), Basiskommentar Steuerrecht (Verlag Dr. Otto Schmidt 2010)

Kemper Martin, 'Erklärungspflichten des Umsatzsteuergesetzes' (2015)

Umsatzsteuer-Rundschau

Lang Fritz in Rüdiger Weimann, Lang Fritz (eds), Umsatzsteuer - national und international (4th edn Schäffer-Poeschel Verlag 2015)

Lang Fritz, 'Taxation of the public sector in Germany - an introduction', in this volume

Langer Ronny, Hammerl Robert, 'Rechnungen im Umsatzsteuerrecht' (2013) Neue WirtschaftsBriefe für Steuer- und Wirtschaftsrecht

Leonard Axel in Bunjes Umsatzsteuergesetz Kommentar (13th edn CH Beck 2014)

Lippross Otto-Gerd, Umsatzsteuer (23th edn Erich Fleischer Verlag 2012)

Schwenker Jörg, 'Das Gesetz zur Modernisierung des Besteuerungsverfahrens - ein Meilenstein auf dem Weg der weiteren Digitalisierung im Steuerrecht' (2016) Der Betrieb 